\title{
Turcot Syndrome Type 2
}

National Cancer Institute

\section{Source}

National Cancer Institute. Turcot Syndrome Type 2. NCI Thesaurus. Code C40464.

An autosomal dominant hereditary neoplastic syndrome caused by mutations in the APC gene. It is characterized by the presence of medulloblastoma and familiar adenomatous polyposis. 